\title{
The Changing Role of NGOs in Britain: Voluntary Action and Illegal Drugs
}

Alex Mold, Centre for History in Public Health, London School of Hygiene and Tropical Medicine ${ }^{1}$

In February 1967 Mollie Craven published an article in The Guardian newspaper entitled 'My son takes heroin.' Craven stated that 'we parents of addicts are a neglected and ignored group. We want to be able to help our pathetic children, even while they cause us suffering which tears us apart. We can help each other.' Craven's appeal for help resulted in the establishment of the Association of Parents of Addicts (APA) an organisation that provided advice to the families of addicts and established a day centre to care for 'young people with serious drug problems." APA later became the Association for the Prevention of Addiction, and more recently still, Addaction. As Addaction it now claims to be Britain's largest specialist drug and alcohol treatment charity, providing services to over 25,000 people in 70 different services throughout the country. ${ }^{4}$ In another article in The Guardian published in 2007 to mark the 40 year anniversary of the founding of APA, journalist Alison Benjamin commented that 'This evolution from a small, self-help and pressure group called the Association of Parents of Addicts (APA) to Addaction, a charity with a $£ 25$ million budget that helps more than 25,000 people a year, is a striking illustration of society's changing relationship with drugs. ${ }^{5}$

This is an accurate assessment, but the experience of organisations like APA is, in some ways, representative not just of changes in the way we deal with drugs, but of the fate of the voluntary sector as a whole. Organisations like Addaction now operate as 'social businesses', offering services to individuals such as drugs users, 
often in place of statutory facilities but largely funded by the government. Such groups act as 'service providers' to government 'commissioners.' This is a marked difference to the early experiences of APA, which was run by volunteers, funded through charitable donations, and received a limited amount of ad hoc support from the London Boroughs Association and the Ministry of Health. ${ }^{6}$ Clearly, it is not just the size of these groups that has altered; the very relationship between voluntary organisations and the state appears to be radically different.

To explore this relationship in more detail this article will take as a case-study the voluntary activity that surrounded illegal drug use from the 1960 s to the present. Focussing on individual case studies allows us to explore important issues surrounding socio-political activity in the twentieth and twenty first century in greater depth. Analysing what Jeremy Kendall and Martin Knapp have called the 'loose and baggy monster' of the third or voluntary sector is potentially overwhelming as this encompasses a huge range of organisations and types of activity. ${ }^{7}$ Looking at one area of action is not only a more manageable enterprise but also generates some bigger questions which can, in turn, be applied to other case studies and the sector as a whole.

A close examination of the voluntary activity around illegal drugs highlights the importance of three chronological phases. The first phase was the period from the 1960 s to the 1970 s, when a significant number of drug voluntary groups first began to appear. The emergence of these groups can be related not just to rising drug use but also to a changing perception of need. Drug users were just one of a number of what Beveridge described as 'distressed minorities', catered for by a string of new organisations. ${ }^{8}$ In the second phase, during the 1980 s, the drug voluntary sector expanded still further as drug use became seen as a major social and political 
problem. Expansion was also facilitated by a significant injection of funds from central government in the form of the Central Funding Initiative (CFI). In some ways this could be seen as indicative of the 'rolling back' of the state, as the state sought to move responsibility for groups like drug users onto voluntary and private organisations. Yet, as will be seen, the state retained a crucial role in coordinating and directing activity. This can also be observed in the final phase, from the 1990s to the present. Since the 1990s, drug users have increasingly come together to form their own groups to agitate for change in the legal framework that regulates drugs as well as to demand improvements in service provision. Whilst some of these groups remain very much outside the state, others appear to have become incorporated within it. This would suggest that despite much interest in the notion of voluntary organisations as key repositories of social capital in civil society, the state remains crucial to any analysis of their wider role.

What the case study of the drugs voluntary sector also reveals is an astonishing diversity of action. Groups were established throughout this period to campaign for drug users; to provide information; to offer legal advice; to provide treatment; to give advice; to coordinate the sector; to advise on service provision and to organise self-help efforts. Considering the nature and impact of these different organisations raises questions about how to describe and interpret this activity. The 'terminological tangle' which surrounds any analysis of the activity that takes place away from the state and the market is a familiar problem, but has particular relevance here. ${ }^{9}$ The term 'NGO' is not one that organisations working in the drugs field have used until very recently, and even then, mainly by groups that operate in an international context. Throughout the period from the 1960s to the present most groups referred to themselves as 'voluntary organisations'. By using the term NGO, 
are we in danger of applying a 'new' concept retrospectively? Moreover, does seeing NGOs not simply as 'non-violent organisations that are neither dependent upon government nor serving an immediate economic interest' but as socio-political 'players' result in a tendency to focus on only the more overtly 'political' organisations ${ }^{10}$

Despite these problems there is no need to discard the label NGO entirely, as it draws attention to the wider role that such organisations play. Indeed, socio-political action assumes many forms. Some groups, such as Narcotics Anonymous (NA), reject the notion that they are political 'players' altogether, although they clearly have a socio-political function. Other organisations, through their complete dependence on the state for financial support, are questionably 'non-governmental'. At the opposite end of the spectrum, there are groups such as Addaction that operate more like businesses. There is clearly a diversity of activity that in a sense defies all simple labels such as 'voluntary organisation', 'NGO' or 'non-profit'. Only by considering a case study in detail can we make sense of this. Focussing on one particular issue can help us to reach a more nuanced understanding of socio-political activism and the various forms that this takes. In this way a 'special interest' becomes of more general concern.

\section{New politics, new problems and new organisations: $1960-1970 \mathrm{~s}$}

Drug use and some of the problems surrounding this has been a focal point for voluntary action since at least the nineteenth century, when Christian organisations such as Spelthorne St Mary and the Sisters of the Community of St Mary the Virgin treated female alcoholics. ${ }^{11}$ Voluntary provision of drug addiction treatment existed alongside private and statutory institutions, but during the 1960s a significant number 
of new voluntary groups appeared. One reason for this growth was the increasing prevalence of drug use. Until the sixties, the use of illegal drugs was comparatively rare in Britain. In 1959 there were 454 known drug addicts, by 1969 there were 1,462: small numbers in comparison to today, but a significant increase none the less. ${ }^{12}$ Moreover, drug use appeared to be becoming a wider social and cultural phenomenon. Newly reported cases of drug addiction tended to be found in young people, and in those who had started taking drugs for recreational, rather than therapeutic purposes. ${ }^{13}$ Drug use and the smoking of cannabis in particular, became a celebrated part of the counter-culture and underground 'scene.' 14 This increase in drug taking brought with it a rise in the medical, social and legal problems associated with drug use, problems which were largely un-catered for by the statutory sector. Indeed, the statutory response to drug use was almost exclusively confined to treatment within NHS Drug Dependence Units and law enforcement by the police. Voluntary groups began to emerge to fill this gap.

At the same time, the expansion of voluntary action in the drugs field was matched by a more general growth in voluntarism in a range of other areas. This can be explained by two key factors. Firstly, by the 1960s confidence in the totality of statutory welfare services was beginning to crumble. ${ }^{15}$ A series of dramatic exposures highlighted significant deficiencies in welfare provision in a number of areas, prompting the establishment of organisations to campaign for, and provide, improvements. ${ }^{16}$ Poverty, for example, was 'rediscovered' and a number of organisations such as the Child Poverty Action Group and Shelter came into being in order to agitate for more resources and better services. ${ }^{17}$ Secondly, an apparently 'new' form of politics and political activity began to develop and take on the interests of Beveridge's 'distressed minorities.' The appearance of new social movements, 
such as those concerned with civil rights, women's rights and the environment, drew attention to previously marginalised groups and interests. ${ }^{18}$ Many new voluntary organisations were established around these issues. Some of these organisations were orientated towards service provision, others took on a more campaigning role, and many combined both.

This pattern of overlapping origins and functions could also be found in the drugs field. The charity Release, for example, which was established in 1967 to provide legal assistance to people arrested for drug offences, also undertook campaigning work in a number of areas. ${ }^{19}$ Release saw their defence of the legal rights of the drug user as a way of providing individual aid, but also as a way of critiquing government policy on drugs. They argued that the drug problem could not be solved by the 'conventional means of criminal reprimand'; they felt that 'medical or social solutions [were] more likely to be successful. ${ }^{, 20}$ To this end Release agitated for reform of the drug laws, and in particular the legalisation of cannabis. They also campaigned for improvements in treatment facilities for drug addicts, especially those using barbiturates and drugs other than heroin. Release lobbied government directly and indirectly, through informal contacts with people like the chief inspector of the Home Office drugs branch, Bing Spear, and by giving evidence to government committees like the Wootton Committee on amphetamines and LSD and the Deedes Committee on police powers of search and arrest in $1969 .{ }^{21}$

It could be argued that despite these efforts, Release's achievements were modest. On key issues, like the legalisation of cannabis, Release appeared to have little success. But, assessing the impact of an organisation like Release on its campaigning activities alone is perhaps unfair. By providing a service - legal aid Release was fulfilling an important role, and one that was just as 'political' as 
campaign work. The presence of organisations like Release presented a covert critique of existing statutory services for drug users and of the notion that the welfare state could provide comprehensively for the needs of all its citizens. At the same time, ensuring that the legal rights of drug users were respected was not simply the giving of aid to vulnerable individuals, but was rooted in a 'new' form of politics interested in different political issues. Caroline Coon, one of the founders of the organisations stated that 'For me, Release was not about drugs per se...For me Release was essentially about civil liberties, legal rights and what we now call human rights. ${ }^{22}$ This wider conception of rights was crucial for dealing with the problems of 'quality of life, equality, individual self-realization, participation and human rights', representative, for Habermas, of a 'new' form politics. ${ }^{23}$ In a sense, therefore, the very existence of projects like Release is perhaps more important than their specific achievements, as it can be seen as evidence for the presence of a different kind of politics and political action. This suggests that there is a need to look at what organisations did more broadly and not just at achievements in the narrow sense of success or failure in bringing about legislative change. By providing services organisations like Release were engaging in a different kind of politics in a different kind of way.

Yet, they could not entirely escape the 'old' politics that surrounded them. As I have argued elsewhere, 'old' political issues revolving around class and gender played a role in shaping Release's activities. ${ }^{24}$ Furthermore, in order to survive financially the organisation accepted a grant from the Voluntary Services Unit (VSU) of the Home Office in 1974. Although there is little evidence to suggest that taking money from the state made Release any less inclined to take on controversial issues or activities, it was an important moment in line with a more general shift. The funding 
of voluntary organisations by the state had been discussed since at least the turn of the century, but from the 1970s onwards statutory funding of voluntary activity became more common. The establishment of the VSU in 1973 and the publication of a series of reports pointing to the value of voluntary action were indicative of a greater degree of interest by the state in the role played by voluntary groups in welfare service provision. 'Old' politics clearly continued to exist alongside the 'newer' variety.

\section{Rolling back the state: the $1980 \mathrm{~s}$}

Indeed, the dynamism around 'new' politics in the 1960s and 1970s, and the emergence of organisations concerned with new problems working in new ways, did not go unnoticed by more conventional political players. By the 1980 s the idea the voluntary organisations could contribute something distinctive and of value was taken on by the New Right. The Conservative government, led by Margaret Thatcher, regarded the state as an inefficient and ineffective provider of welfare, and considered its monopoly on the provision of services to have resulted in a culture of passivity and dependence amongst welfare recipients. ${ }^{25}$ The suggested solution to this problem was to 'roll back the state'; to reduce the role of central government in the provision of welfare. The 'rolling back of the state' was to be achieved in two closely related ways. Firstly, by placing greater emphasis on the involvement of voluntary organisations in the delivery of health and social services; and secondly by creating a 'market' in welfare, allowing statutory and non-statutory bodies to bid for contracts to provide specific services. ${ }^{26}$ In both these developments the role of the voluntary sector was crucial. Not only was the voluntary sector regarded as being more responsive, more innovative and more cost-effective than the statutory sector, it was 
also thought to be able to reduce reliance on the state through the 'invigorating' experience of self-help and community care. ${ }^{27}$

The drugs field was a crucial test area for such a policy. During the 1980s illegal drug use in Britain appeared to be increasing at an alarming rate and spreading across the country on an unprecedented scale. An apparent growth in the use of heroin caused particular concern: the number of known heroin addicts rose from just over 2,000 in 1977 to more than 10,000 by $1987 .{ }^{28}$ Moreover, heroin use was being reported in urban areas throughout the country. ${ }^{29}$ This was in contrast to previous decades, when it was thought that drug use was largely confined to London. ${ }^{30}$ To combat this seemingly worsening problem, the government introduced the Central Funding Initiative (CFI) for drug services in 1982. Initially, the CFI was designed to provide $£ 6$ million over three years to organisations providing services to drug users throughout the country, but the programme was extended in January 1986, partly in response to the discovery of HIV/AIDS amongst injecting drug users. Under the initiative a total of $£ 17.5$ million pounds was awarded between 1983 and $1989 .^{31}$ What was significant about the CFI was that it was open to service providers in both the statutory and voluntary sector. In and of itself statutory funding of voluntary groups in the drugs field was nothing new. Various voluntary groups involved in caring for drug users had received funding from the Home Office (like Release) and the Department of Health and Social Security (DHSS) as well as local authorities. Most of this funding, in line with more general support for non-statutory groups in the health field, was provided under Section 64 of the Public Health Services and Public Health Act, 1968 and largely confined to headquarters administrative expenses for voluntary bodies working on a national basis. ${ }^{32}$ Both the coordinating body the Standing Conference On Drug Abuse (SCODA) and the 
Institute for the Study of Drug Dependence, a drugs information service and specialist library, received funding in this manner. ${ }^{33}$ Smaller, local groups tended to receive funds on an ad hoc basis or from local authorities, such as the London Boroughs Association. ${ }^{34}$ Most agencies, however, were chronically under-funded. The government's expert group on drug issues, the Advisory Council on the Misuse of Drugs, noted in 1982 that 'The non-statutory agencies involved in treatment and rehabilitation rely on an insecure combination of local and central government funding and exist under the constant threat of financial collapse. 35

Yet, providing central funds for voluntary organisations in order to prevent them from disappearing was not the sole reason for opening up the CFI to nonstatutory groups. A DHSS circular informing regional authorities of the introduction of the CFI stated that its purpose was

not to remove from statutory authorities the responsibility for providing services and training but, by making additional funds available to them and to voluntary organisations, to remedy more rapidly than would otherwise have been possible, the inadequacy of the network of services for people with drug related problems. ${ }^{36}$

Fostering the participation of voluntary organisations was vital because, as Undersecretary of State for Health and Social Security, John Patten, told MPs, there was a realisation that 'the problem is not necessarily going to be ameliorated and controlled...by action within the National Health Service alone.' Moreover, 'A very great deal of expertise, in terms of prevention and counselling, is in the voluntary sector, not in the National Health Service. ${ }^{37}$ Yet, non-statutory groups did not just provide expertise: there was a feeling amongst DHSS officials that voluntary organisations offered something statutory authorities could not. A senior civil servant in charge of the CFI asserted that voluntary groups 'could be more flexible in what they did' that as they 'were not tied to a specific service approach...they were more 
willing to initiate different types of services. ${ }^{, 38}$ The CFI, by offering substantial funding to voluntary organisations, was designed to make use of this. Even so, a senior civil servant remarked that 'we were quite surprised that we got so many applications from the voluntary sector'; clearly developments on the ground had been somewhat invisible at the central policy level. ${ }^{39}$ However, once the DHSS were aware of the extent of voluntary sector involvement in the field a clear commitment was made to enhancing its role in drug service provision. This can be seen in the grants made under the CFI: of the 188 grants issued, 58 per cent went to statutory organisations and 42 per cent to non-statutory groups. ${ }^{40}$ Such significant support for voluntary organisations cannot be explained by necessity alone: this must be related to a much broader strategy for involving the non-statutory sector in health and social service provision.

Indeed, in many ways, the CFI for drug services represents a microcosm of key aspects of Conservative welfare policy in this period. The term 'initiative' was a particular favourite of the Thatcher administration. Numerous 'initiatives' were launched to tackle a range of social issues particularly in the inner-cities. Urban development grants, for example, were designed to foster regeneration by using public funds to pump-prime development in areas such as the London Docklands and Merseyside. Central to these policies was the notion of 'partnership' with private companies and voluntary organisations which would be expected to support projects in the long-term. ${ }^{41}$ In the health field, 'initiative' had a particular meaning. From 1982 onwards a number of central funding initiatives were launched in areas where the government wanted to raise standards. ${ }^{42}$ A DHSS official noted that 'The funding of schemes is deliberately limited in duration to preserve their development and catalyst role. They are not intended as a prolonged substitute for local funding'. 
Health and local authorities were expected to find the money for continuing schemes from within their regular sources of funding and voluntary bodies were required to carry on raising their own funds. ${ }^{43}$

Such a scheme cast central government in the role of initiator of new services rather than their long-term funder. The central funding initiatives thus encapsulated a key aspect of the Thatcherite policy of 'rolling back the state': reducing direct statutory involvement in welfare provision by changing the function of the state from that of provider, to manager, but through a command and control model. This transition was later confirmed through the NHS Care and Community Act in 1990. The act created an internal market within health and social care by establishing a divide between the 'purchasers' of services and the 'providers' of these. Local authorities, for example, were able to 'purchase' a particular service, such as a needle exchange for injecting drug users, from a local 'provider.' The 'provider' could be a statutory, voluntary or private organisation; these were expected to 'compete' within the internal market for the custom of the 'purchaser.' Competition, it was argued, would make services more cost-effective and responsive to consumer demand. ${ }^{44}$

The creation of the internal market, it has been suggested, helped to replace 'welfare statism' with 'welfare pluralism' as a range of organisations took on functions previously performed by the state. ${ }^{45}$ Within this 'mixed economy of care' particular significance was placed on the part played by voluntary organisations. ${ }^{46}$ The voluntary sector was regarded as being more flexible than the statutory sector and, crucially, more able to enhance citizen participation. ${ }^{47}$ Reliance upon the state could be further reduced as individuals were encouraged to help themselves and their communities. ${ }^{48}$ Of course there is a paradox here - as statutory support for voluntary organisations increased elements of what was distinctive about the voluntary, as 
opposed to the statutory, sector could be seen to have diminished. ${ }^{49}$ Susanne MacGregor and Ben Pimlott asserted that some organisations were transformed into 'de facto agencies of the state, which financed them and indirectly determined their

policy. ${ }^{50}$ Such a situation clearly raises questions about how non-governmental many supposedly non-governmental agencies really were.

\section{Non Governmental or newly governmental? NGOs and drugs 1990s-present}

Issues surrounding the independence of voluntary organisations reliant upon statutory funding persisted into the 1990s and beyond. Indeed, the more marketised approach to public services resulted in the proliferation of different groups, but many of these were often tied (to a greater or lesser extent) to the state. The introduction of service agreements, or contracts, between a local authority purchaser and voluntary or private sector providers in the 1990s had a significant effect on the way voluntary organisations operated. Contracts imposed professional standards of assessment, management and evaluation on voluntary agencies. For many volunteers, this appeared to threaten the very nature of voluntarism. Some organisations were also concerned that contracting could compromise their campaigning roles and diminish their autonomy. Still others were worried that contracting would make their organisations more bureaucratic and formalised. ${ }^{51}$

Evidence from the drugs field suggests that at least some of these fears have been realised. Statutory support for voluntary organisations in the drugs field continued apace in the 1990s. This was initially spurred on by the need to combat HIV/AIDS, but more recently has tended to focus on treatment provision and on breaking the supposed link between drug use and crime. One expert observer of the drugs field who had worked in the drug voluntary sector for more than 25 years noted 
that 'there's been a lot more money coming into the field, and some voluntary agencies have done quite well out of this'. ${ }^{52}$ Key organisations, like Addaction, have become very big service providers. Other groups have diversified. Turning Point, which as Helping Hand worked with drug and alcohol users in the 1960s and 1970s, brands itself as a 'social care' organisation, annually offering services to approximately 130,000 people with 'complex needs'. ${ }^{53}$ Such organisations are 'social businesses' providing services on behalf of the state and as a result, a veteran voluntary sector worker observed, have 'become more tied into central government.' This, he contended, raised questions about the 'degree to which you can be an independent critique of government... while at the same time being drawn closer and closer together, tied closer and closer in because of funding schemes. ${ }^{, 54}$

However, the social business model is by no means the only form that voluntarism around illegal drugs has taken in recent years. The creation of a quasimarket in public service provision has also resulted in greater attention being paid to the views of users of services themselves. Since the 1990 s there have been a string of schemes aimed at involving the patient or service user in decisions about their own care and wider service provision. The introduction of the Children Act in 1989 and the National Health Service and Community Care Act in 1990 required local and health authorities to consult with voluntary organisations and users in planning and decision making. ${ }^{55}$ The Citizen's Charter, established in 1991, gave users of public services a series of rights and expectations to be drawn on when dealing with service providers. ${ }^{56}$ These were built on by the Labour government in the NHS Plan of 2000, and its desire to create a 'patient-centred' NHS. ${ }^{57}$ In 2001, the Health and Social Care Act made it a statutory obligation for health and social services to involve service 
users in the planning and delivery of services. Greater attention was being paid to the recipient of public services in all areas.

The impact of these developments on the drugs field can be seen at the national and local level. In 2001 the National Treatment Agency (NTA) was established. This special health authority was tasked with improving the availability and effectiveness of, and access to, treatment services. Involving drug users was seen as being central to their work. As well as funding research to find out what drug users views of treatment were, the NTA supported attempts to establish a national users' organisation and provided financial assistance to groups such as the Methadone Alliance (now known just as the 'Alliance') who provide advocacy and support for drug users in treatment across the country. Drug users were also represented on the NTA's board. This level of user representation was carried forward to the regional level too. Local drug services, commissioned by Drug Action Teams or DATs, were also required to involve drug users in decisions about services. Most DATs now support a user group for their region, who comment on service delivery and future planning.

Yet, alongside this state-sponsored user involvement there are other kinds of user groups that exist largely outside the state. Not only do we see the involvement of active users, but also of user activists. The groups and individuals behind drug user produced publications like Black Poppy and the Users' Voice, and organisations such as the John Mordaunt Trust, the UK Harm Reduction Alliance and Transform, often took a more challenging stance. Like the early gay AIDS organisations these groups have their own agendas which do not necessarily fit with those of the government. ${ }^{58}$ In interviews with user activists three issues have emerged as central concerns. The 
first issue was the potentially empowering effect of user involvement. One user activist described empowerment in the following terms:

user involvement can be so empowering, because it empowers you not just if your working in your clinic... [to] get better conditions for the clients of the service and for the staff that work in it, and solutions to issues. But also in your life: the knock on effect that having a voice can have is enormous... it's about, I think, we feel, taking your control back. ${ }^{59}$

With empowerment has come increased attention to the second issue: drug users' rights. These rights are increasingly being conceptualised not just in the sense of a right to certain kinds of treatment or even input into treatment, but in a broader, human rights sense. Another long-standing user activist commented that: 'the main thing that I really felt that [is] different from the early days is that everybody suddenly started talking about their right to use drugs. ${ }^{60}$ From this, almost inevitably, have come calls for changes in the drug laws, the third issue to emerge strongly from interviews with user activists. Many user activists believe that drugs should be legalised, even if some do not think this is a realistic goal. A male user activist commented that 'I see the anti-prohibition and treatment side as being absolutely inextricably linked'. He went on to say that 'I think the users' movement has to challenge prohibition. If it doesn't, it's incomplete. It's just a service lobby. ${ }^{, 61}$

The interest of drug users in issues such as these surrounding rights, representation and empowerment, hint at the emergence of a social movement. The appearance of similar groups in other countries, particularly in the Nordic states, has led some commentators to posit the existence of an international drug users' movement. ${ }^{62}$ Moreover, as the quotations from drug user activists in Britain demonstrate, the state and users do not always agree on the meaning and purpose of user involvement. For some drug users, user involvement is not just about improving service provision, but about broader social and political goals. Yet for the state, user 
involvement is seen as a way of making services more responsive to the needs of the consumer, as a vital tool within the increasingly marketised welfare state. These different objectives may well bring users into conflict with the state. Yet, there are significant limitations to user power. Working closely with local or national government might enable some users to gain access to policy-making circles and effect change, but the charge sometimes levelled at user involvement is that can be tokenistic. User activists in the drugs field, and in other areas, have often described user involvement in services as being a box-ticking exercise, as another task for bureaucrats. $^{63}$

At the same time, drug users are clearly not a homogenous mass who all want the same thing. This has led some critics to question how far it is possible for user groups to be representative. A former senior worker in the drugs voluntary sector commented that 'the user groups we hear about tend to be about those user groups who are currently using. We don't hear very much about, from the other perspectives, for instance from the NA. ${ }^{64}$ He contended that 'the biggest user groups are NA', an argument that would seem to be born out by NA's claim that there are at least 500 separate weekly NA meetings held across the UK today. ${ }^{65}$ Yet, NA is an organisation that outwardly rejects any notion of political engagement by refusing to 'express opinions on any civil, social, medical, legal or religious issues.' NA describe themselves as a 'non-profit fellowship of men and women for whom drugs had become a major problem - recovering addicts who meet regularly to help each other stay clean.' Membership is, by its very nature, anonymous and directed inwards at 'working with each other to achieve recovery. ${ }^{, 66}$

Despite this, NA clearly has a socio-political presence. The recent growth in abstinence-orientated self-help groups for drug users like NA (the number of weekly 
NA meetings has more than doubled since 1991) is having an impact, especially on treatment provision. ${ }^{67}$ Within drug addiction treatment there seems to be a move away from the long-term prescription of methadone to addicted patients and towards a greater emphasis on abstinence orientated programmes, similar to those run by NA. ${ }^{68}$ This would suggest that NA do have a degree of socio-political influence. Yet, their outward denial of a political function would appear to be significant. NA's apparent refusal to engage makes them difficult to situate: they do not seem to be like other political 'players' in the drugs field, but are evidently more than 'just' a self-help group. Here is an organisation that is obviously 'political', despite their rejection of such a role.

\section{Conclusion}

The problem of how to describe and explain NA is, to an extent, indicative of wider difficulties with describing and explaining the sector as a whole. Much of the activity around illegal drugs in this period was directed towards service provision. Groups that had a campaigning aspect to their work, like Release, usually combined this with other more service orientated activity. But, this does not mean that their activity was necessarily less 'political' than the more vocal organisations found in other fields. Indeed, by providing services not only were these groups criticising statutory provision (or the lack of) they were attempting to find a solution to a problem that they had themselves identified. Taking a case-study approach, therefore, highlights the importance of the seemingly more 'quiet' and apparently less radical groups and organisations. This would suggest that judgements about the impact of NGOs should not be seen simply in terms of the success or failure of specific campaigns, but about new ways of dealing with new problems. Indeed, the diversity of action pointed to by 
this article, especially when coupled with change over time, might lead us to conclude that it is impossible to say anything definitive about the role of voluntary organisations (or NGOs) across one sector, let alone as a whole. But, if we are dealing with a 'new' form of socio-political engagement then perhaps we need to look to new ways of describing and assessing this activity.

Indeed, when developing new modes of analysis understanding the context in which these groups formed and operated must remain crucial. The case study examined in this article points to the relevance not only of the micro-politics of one sector, but also to the macro-politics of changing ideas about voluntarism, the state and socio-political action. Voluntary groups that sprang up to cater for the 'distressed minorities' of the 1960s and 1970s were seen largely as plugs to fill the gaps in a leaky welfare state; in the 1980 s they were to be 'rolled in' to a welfare state that was never fully 'rolled back'; in the 1990s they were drawn into still closer relationships with the state through contracts, and since 2000 have provided consumer or user input into services. Yet, at the same time, voluntary groups appeared independently of the state and were often critical of its actions. This can be seen most recently in the emergence of a drug user movement that seeks to challenge government policy on drugs in a number of crucial areas. If, as Frank Prochasaka has observed, some charities are 'swimming into the mouth of Leviathan' others seem to be succeeding in giving it in indigestion. ${ }^{69}$

7197 including notes

\footnotetext{
${ }^{1}$ This article is based on research undertaken for an Economic and Social Research Council funded project (grant reference number ESRC RES-000-23-0265) held by
} 
Professor Virginia Berridge. For a more detailed exploration of this work see A. Mold and V. Berridge, Voluntarism, Health and Society Since the 1960s: Voluntary Action and Illegal Drugs (Palgrave, forthcoming). Sections of this article are reproduced with permission from A. Mold and V. Berridge, 'Crisis and opportunity in drug policy: changing the direction of British drug services in the 1980s', Journal of Policy History, 19:1 (2007), pp. 29-48; and A. Mold and V. Berridge, The "rise" of the user? Voluntary organisations, the State and illegal drugs, since the 1960s', Drugs: Education, Prevention and Policy (forthcoming, 2008).

${ }^{2}$ M. Craven, 'My son takes heroin', The Guardian 24 February 1967.

${ }^{3}$ Association for the Prevention of Addiction (APA) Newsletter, November 1970, Modern Records Centre, University of Warwick, (MRC) MSS.171/3/18/2.

${ }^{4}$ See http://www.addaction.org.uk/.

${ }^{5}$ A. Benjamin, 'We can help each other' The Guardian G2, 22 February 2007, 10-13.

${ }^{6}$ Grants under Section 64 of the Health Services and Public Health Act, 1968 - Drug Addiction; Position in October 1972; London Boroughs Association, Report of General Purposes Committee, 22 November 1972, The National Archives, London (TNA), MH 154/430.

${ }^{7}$ J. Kendall and M. Knapp, 'A loose and baggy monster: boundaries, definitions and typologies' in J. Davis Smith, C. Rochester and R. Hedley, An Introduction to the Voluntary Sector (London: Routledge, 1995).

${ }^{8}$ Beveridge quoted in G. Finlayson, Citizen, State and Social Welfare in Britain 18301990 (Oxford: Oxford University Press, 1994) p. 328.

${ }^{9}$ Phrase 'terminological tangle' quoted in N. Deakin, In Search of Civil Society (Basingstoke: Palgrave, 2001) p. 9.

${ }^{10}$ Discussion Points for the DANGO Conference, 5-6 July 2007. 
${ }^{11}$ H.B. Spear, Heroin Addiction Care and Control: The British System 1916-1984 (London: DrugScope, 2002) p. 52.

${ }^{12}$ Figures from H.B. Spear, 'The growth of heroin addiction in the United Kingdom', British Journal of Addiction, 64, (1969), pp. 245-255; p. 247; G. Stimson and E. Oppenheimer, Heroin Addiction: Treatment and Control in Britain (London: Tavistock, 1982); pp. 208-9.

${ }^{13}$ See Ministry of Health, Drug Addiction: Report of the Second Interdepartmental Committee (London: HMSO, 1965) p. 5.

${ }^{14}$ J. Green, All Dressed Up: The Sixties and the Counterculture (London: Pimlico, 1999) pp. 173-201.

${ }^{15}$ Finlayson, Citizen and State, p. 329.

${ }^{16}$ N. Deakin, 'The perils of partnership: the voluntary sector and the state 1945-1992', in Davis Smith, Rochester and Hedley, An Introduction to the Voluntary Sector, pp. 49-50.

${ }^{17}$ See article by Evans in this volume.

${ }^{18}$ J. Habermas, 'New social movements', Telos, 49 (1981) pp. 33-37; P. Byrne, Social Movements in Britain (London, 1997); N. Crossely, Making Sense of Social Movements (Buckingham, 2002).

${ }^{19}$ A. Mold, “"The welfare branch of the alternative society?" The work of drug voluntary organisation Release, 1967-1978', Twentieth Century British History, 17:1 (2006) pp. 50-73.

${ }^{20}$ C. Coon and R. Harris, The Release Report On Drug Offenders and the Law (London, 1969) pp. 36-37.

${ }^{21}$ Written statement for the ACDD Search and Arrest Committee, 1969, MRC MSS.171/3/12/13; d'Agapeyeff, Release, Section XII; C, MRC MSS.171/5/1/2. Coon, 
'We were the welfare branch of the alternative society' in $\mathrm{H}$. Curtis and M.

Sanderson, The Unsung Sixties: Memoirs of Social Innovation (London: Whiting \& Birch, 2004), p. 190.

${ }^{22}$ Coon, 'We were the welfare branch of the alternative society' p. 185.

${ }^{23}$ Habermas, 'New social movements'.

${ }^{24}$ Mold, "The welfare branch of the alternative society"? , pp. 50-73.

${ }^{25}$ Finlayson, Citizen, State and Social Welfare in Britain, pp. 357-60.

${ }^{26}$ Deakin, 'The perils of partnership': pp. 54-62; J. Kendall and M. Knapp, The Voluntary Sector in the United Kingdom (Manchester: Manchester University Press, 1996) pp. 201-5; J. Lewis, 'Developing the mixed economy of care: emerging issues for voluntary organisations', Journal of Social Policy, 22:2 (1993) pp. 173-92.

${ }^{27}$ For an overview of welfare policy under Thatcher see R. Lowe, The Welfare State in Britain Since 1945 ( $3^{\text {rd }}$ edition, Basingstoke: Palgrave, 2005) pp. 317-27; pp. 35057.

${ }^{28}$ Home Office, Statistics of Drug Addicts Notified to the Home Office, 1988 (London: HMSO, 1989).

${ }^{29}$ Advisory Council on the Misuse of Drugs, Treatment and Rehabilitation (London: HMSO, 1982), p. 25.

${ }^{30}$ Ministry of Health, Drug Addiction: Report of the Second Interdepartmental Committee, p. 8.

${ }^{31}$ S. MacGregor et al., Drug Services in England and the Impact of the Central Funding Initiative (London: ISDD, 1991) p. 1.

${ }^{32}$ Letter from Mr JC Eversfield, DHSS to Mr Platten, Town Clerk London Borough of Enfield, 20 December 1971; TNA MH 154/433. 
${ }^{33}$ For SCODA see TNA MH 154/1192, and SCODA annual reports in DrugScope Library; for ISDD see TNA FD 23/1949 and ISDD annual reports in DrugScope Library.

${ }^{34}$ Heroin addiction: London Boroughs Association; working party reports on rehabilitation, 1968-1974, TNA MH 154/430.

${ }^{35}$ ACMD, Treatment and Rehabilitation (London: HMSO, 1982), p. 77.

${ }^{36}$ Letter from DHSS to all Regional Health Authorities regarding Treatment and Rehabilitation report of the ACMD; Central Funding Initiative, (HN (83) 13 LASSAL (83) 1), 25 April 1983, Department of Health Archive, Nelson, Lancashire (DOHA) OCG/1/1/3.

${ }^{37}$ House of Commons, Fourth Report from the Social Services Committee, Session 1984-1985: Misuse of Drugs (London: HMSO, 1984-1985) DHSS evidence, p. 170.

${ }^{38}$ Interview conducted by Mold and Berridge with senior civil servant, 2/05/06.

${ }^{39}$ Ibid.

${ }^{40}$ MacGregor et al., Drug Services in England and the Impact of the Central Funding Initiative, pp. 71-74.

${ }^{41}$ On urban initiatives see S. MacGregor and B. Pimlott, 'Action and inaction in the cities' in S. MacGregor, and B. Pimlott, (eds.) Tackling the Inner Cities: The 1980s Reviewed, Prospects for the 1990s (Oxford: Clarendon Press, 1990).

${ }^{42}$ Note on Central Initiatives by John H James, 30 April 1986, DOHA, DAC/0007/V0004; Memorandum from DC Nye to Mr Alderman, Miss Davies, Mr Hillier, Mr Lutterloch, Mr Pagan and Mr Woolley, regarding new initiatives, 14 December 1983, DOHA, DAC/0026/V001.

${ }^{43}$ Note on Central Initiatives by John H James, 30 April 1986; DOHA, DAC/0007/V0004. 
${ }^{44}$ On changes in the welfare state in this period see Lowe, The Welfare State, pp. $317-$ 327.

${ }^{45}$ M. Harris, C. Rochester and P. Halfpenny, 'Voluntary organisations and social policy: twenty years of change', in M. Harris and C. Rochester (eds.) Voluntary Organisations and Social Policy in Britain: Perspectives on Change and Choice (Basingstoke: Palgrave, 2001), p. 3.

${ }^{46}$ Lewis, 'Developing the mixed economy', pp. 173-92.

${ }^{47}$ Kendall and Knapp, The Voluntary Sector in the UK, p. 138; Deakin, 'The perils of partnership', p. 54.

${ }^{48}$ Lowe, The Welfare State in Britain, p. 320.

${ }^{49}$ Lewis, 'Developing the mixed economy', pp. 183-191.

${ }^{50}$ MacGregor and Pimlott, ‘Action and inaction', p. 9.

${ }^{51}$ Lewis, 'Developing the mixed economy', pp. 183-91.

${ }^{52}$ Interview conducted by Mold and Berridge with drug voluntary sector worker, $14 / 01 / 05$.

${ }^{53}$ See http://www.turning-point.co.uk/About+Us/

${ }^{54}$ Interview with drug voluntary sector worker.

${ }^{55}$ M. Locke, P. Robson and S. Howlett, 'Users: at the centre or on the sidelines?' in Harris and Rochester, Voluntary Organisations and Social Policy In Britain, pp. 199212.

${ }^{56}$ Cm 1599, The Citizen's Charter (London: HMSO, 1991).

${ }^{57}$ Cm 4818, NHS Plan: A Plan for Investment, A Plan for Reform, (London: The Stationery Office, 2000). 
${ }^{58}$ On AIDS groups see V. Berridge, 'AIDS and the rise of the patient? Activist organisation and HIV/AIDS in the UK in the 1980s and 1990s', Medizin Gesellschaft und Geshichte, 21 (2002) pp. 109-123.

${ }^{59}$ Interview conducted by Mold with a user activist, 19/07/05.

${ }^{60}$ Interview conducted by Mold with a long-standing user activist, 13/12/05.

${ }^{61}$ Interview conducted by Mold with a male user activist, 30/05/06.

${ }^{62}$ J. Anker, et al , 'Introduction' in Drug Users and Spaces for Legitimate Action (Nordic Council for Alcohol and Drug Research: Finland, 2006) p. 7.

${ }^{63}$ See, for example, J. Birchall and R. Simmons, User Power: The Participation of Users in Public Services (London: National Consumer Council, 2004) and F. Branfield and P. Beresford, Making User Involvement Work: Supporting Service User Networking and Knowledge (York: Joseph Rowntree Foundation, 2006).

${ }^{64}$ Interview between Mold and a former senior drug voluntary sector worker, $25 / 02 / 05$.

${ }^{65}$ See http://www.ukna.org/.

${ }^{66}$ Ibid.

${ }^{67}$ B. Wells, 'Narcotics Anonymous in Britain: the stepping up of a phenomenon,' in Heroin Addiction and the British System, Vol 2, ed. by J. Strang and M. Gossop, (London: Routledge, 2005) p. 168.

${ }^{68}$ T. Carnwarth and C. Ford, "Methadone challenged on its home turf: is there a worrying methadone backlash about?” Drink and Drug News (8 May 2006) p. 9. ${ }^{69}$ F. Prochaska, 'Voluntary action - renaissance or decline?' downloaded from http://www.historyandpolicy.org/Voluntary\%20action.pdf. 